\title{
KONSEP PENDIDIKAN PLURALISME DALAM PERSPEKTIF NURCHOLISH MADJID
}

\author{
Musayyidi \\ STIT Al-Karimiyyah Sumenep \\ Rasuki \\ STIT Al-Karimiyyah Sumenep
}

\begin{abstract}
Allah SWT. menciptakan manusia dengan bermacam-macam perbedaan agar saling berinteraksi mengenal antara satu dengan yang lainnya. Perbedaan bangsa dan suku tentu akan melahirkan bermacam budaya yang ada di masyarakat. Keragaman dan perbedaan dalam kehidupan manusia merupakan sunnatullah. Al-Qur'an sebagai representasi pesan-pesan Allah untuk menjadi panduan umat manusia, sesungguhnya telah memberikan beberapa isyarat penting, baik secara eksplisit maupun implisit tentang eksistensi keragaman dan perbedaan tersebut. Pelaksanaan pendidikan Islam berbasis dan berwawasan pluralisme tersebut semakin dirasakan urgen dan mendesak jika dikorelasikan dengan kenyataan bahwa kemajemukan agama dan kemajemukan lainnya, seperti kemajemukan etnis, antar golongan dan kemajemukan lainnya belakangan ini telah menjadi suatu hal yang memancing eskalasi konflik yang sedemikian mengental pekat.
\end{abstract}

Keywords: Pendidikan, Pluralisme, Nurcholish Madjid 
Musayyidi \& Rasuki

\section{Pendahuluan}

Pluralisme merupakan kenyataan bahwa dalam suatu kehidupan manusia terdapat keragaman suku, ras, budaya, dan agama. Keragaman itu bisa terjadi karena adanya faktor lingkungan tempat manusia hidup yang berbeda-beda. Lingkungan empat musim bagi seseorang akan membuat orang tersebut memiliki karakter dan pembawaan yang berbeda dengan orang yang hidup dalam lingkungan dua musim.

Nurcholis Madjid yang juga dikenal sebagai bapak pluralisme, berpendapat bahwa Pluralisme tidak dapat dipahami hanya dengan mengatakan bahwa masyarakat kita majemuk, beraneka ragam, terdiri dari berbagai suku dan agama ${ }^{1}$, yang justru hanya menggambarkan kesan fragmentasi, bukan pluralisme. Pluralisme juga tidak boleh dipahami sekedar sebagai "kebaikan negatif" (negative good), hanya ditilik dari kegunaannya untuk menyingkirkan fanatisme.

Sementara pluralisme yang ditekankan Abdurrahman Wahid adalah pluralisme dalam bertindak dan berpikir. Pluralisme dalam bertindak mensyaratkan seseorang untuk tidak membatasi pergaulan dengan orang lain (eksklusif) meskipun berbeda keyakinan. Pluralisme dalam berpikir adalah kesediaan untuk menerima atau mengambil gagasan atau pemikiran dari kalangan lain.

Pluralisme harus dipahami sebagai pertalian sejati kebhinekaan dalam ikatan-ikatan keadaban. Bahkan juga suatu keharusan bagi keselamatan ummat manusia, Dengan demikian, hal tersebut menegaskan adanya masalah besar dalam kehidupan beragama yang ditandai oleh kenyataan pluralisme dewasa ini. ${ }^{2}$ Salah satu cara dalam membentuk model kehidupan yang bersifat kolektif sebagai sebuah masyarakat dalam berbangsa dan bernegara, adalah melalui promosi dan aplikasi Pendidikan Islam berbasis pluralisme

Pelaksanaan pendidikan Islam berbasis dan berwawasan pluralisme tersebut semakin dirasakan urgen dan mendesak jika dikorelasikan dengan kenyataan bahwa kemajemukan agama dan kemajemukan lainnya, seperti kemajemukan etnis, antar golongan dan kemajemukan lainnya belakangan ini

\footnotetext{
${ }^{1}$ Para ahli ilmu perbandingan agama membagi agama secara garis besar ke dalam dua bagian. Pertama, kelompok agama yang diturunkan oleh Tuhan melalui wahyu-Nya yang disebut sebagai agama samawi atau agama langit (antara lain; Islam, Yahudi dan Nashrani). Kedua,kelompok agama yang didasarkan pada hasil renungan mendalam dari tokoh yang membawanya sebagaimana terdokumentasikan dalam Kitab Suci yang disusunnya, agama demikian disebut sebagai agama ardli atau agama bumi (seperti; Hindu, Budha, Majusi, Konghucu, dsb.), lihat Abudin Nata, Metodologi Studi Islam, (Jakarta: PT. Raja Grafindo Persada, 2009), 119.

2 Budhi Munawwar-Rachman, Islam Pluralis, Wacana Kesetaran Kaum Beriman, (Jakarta: PT. Raja Grafindo Persada, 2004), 39.
} 
telah menjadi suatu hal yang memancing eskalasi konflik yang sedemikian mengental pekat sebagaimana telah disinggung di atas. Pada sisi lain, kondisi pendidikan agama yang diajarkan di sekolah sangatlah memprihatinkan. ${ }^{3}$

Atas dasar itu, sosialisasi dan internalisasi nilai-nilai pluralisme secara aktif intensif sejak dini kepada terdidik sangat mendesak sehingga diharapkan nantinya mereka terbiasa dengan suasana berbeda, bahkan memandang perbedaan dan keberbagaian dalam seluruh aspek kehidupan merupakan sesuatu yang sudah semestinya, dalam arti tidak dapat ditolak eksistensinya, sekaligus pada saat yang sama secara teologis menyadari bahwa fenomena demikian merupakan Sunnatullah.

Upaya sosialisasi dan internalisasi nilai-nilai pluralisme tersebut antara lain disuarakan oleh Nurcholish Madjid. Diakui "hampir seluruh usia karir intelektual Nurcholish Madjid dihabiskan untuk mengembangkan paham pluralisme, (dalam arti yang seluas-luasnya). Dengan memperhatikan pendidikan Islam pluralisme dalam kontek keindonesiaan yang sebenarnya dan bagaimana implementasinya dalam pendidikan Islam. Dalam kontek realitas sosial pendidikan Islam pluralisme adalah sebuah tawaran solusi bagaimana aplikasi sebuah sistem pendidikan yang sesuai dengan sistem pendidikan Islam dan Indonesia. Dengan alasan ini, maka salah satu aspek pendidikan adalah Edukasional serta agama ${ }^{4}$.

\section{Biografi Prof. Dr. Nurcholish Madjid}

Nurcholish Madjid (selanjutnya kita akan sebut "Cak Nur" saja, seperti panggilan akrabnya) lahir pada tanggal 17 Maret 1939 M dan bertepatan 26 Muharram 1358, di Jombang, sebuah kota Kabupaten di Jawa Timur. Nurcholish Madjid diberi nama oleh orang tuanya dengan nama Abdul Malik. Perubahan nama menjadi Nurcholish Madjid terjadi pada usia 6 tahun, karena Abdul Malik kecil sering sakit. Dalam tradisi Jawa, anak yang sering sakit dianggap "kabotan jeneng" (keberatan nama) dan karena itu perlu diganti. Nurcholish Madjid dibesarkan dalam kultur pesantren Berasal dari keluarga NU (Nahdlatul Ulama) tetapi berafiliasi politik modernis, yaitu Masyumi ${ }^{5}$.

Ayahnya, H. Abdul Madjid, seorang kyai lulusan pesantren Tebuireng, yang didirikan oleh KH. Hasyim Asy'ari. Ayah Nurcholish memiliki hubungan

\footnotetext{
${ }^{3}$ Nurcholis Madjid Islam Doktrin Peradaban, (Jakarta: Paramadina. 2008) 173-174

${ }^{4}$ H.A.R. Tilaar. Kekuasaan dan pendidikan "Suatu Tinjauan dari Perspektif Studi Kultural" (Indonesiatera, Magelang, 2003), Hal. 167-168.

5 Budhy Munawar-Rachman, Ensiklopedi Nurcholish Madjid" Pemikiran Islam di Kanvas Peradaban", (Jakarta: Mizan, 2006), liv.
} 
Musayyidi \& Rasuki

yang sedemikian dekat dengan tokoh pendiri Nahdhatul Ulama (NU) ini, yaitu sebagai murid dan sebagai menantu dari keponakan KH. Hasyim Asy'ari, Halimah, sebelum akhirnya bercerai secara baik-baik karena tidak memiliki keturunan. Hadrat al-Shaikh KH. Hasyim Asy'ari pula yang mencarikan jodoh untuk istri berikutnya yang kemudian menjadi ibu kandung Nurcholish yaitu $\mathrm{Hj}$. Fathonah,62 putri dari KH. Abdullah Sadjad, yang juga teman karib KH. Hasyim Asy'ari. ${ }^{6}$

Posisi ayahnya yang tetap berpegang pada kebiasaan NU dalam hal keagamaan, namun berafiliasi kepada Masumi dalam hal politik, juga membawa pengaruh kepada Nurcholish Madjid. Dalam hal ini, Abdul Madjid nampaknya ingin menunjukkan bahwa dasar keagamaan seseorang tidak menghalanginya untuk berafiliasi dengan partai politik tertentu yang berbeda dengan dasar keagamaannya. Artinya, Abdul Madjid ingin menunjukkan bahwa partai politik bukanlah sesuatu yang mutlak berkaitan dengan agama. Tetapi, partai politik hanya merupakan sarana untuk mencapai tujuan, ia bukan tujuan itu sendiri. Oleh karena itu, partai politik bukanlah yang terpenting. Di kemudian hari, pemikiran ini menjadi lebih jelas dalam pemikiran Nurcholish Madjid dengan konsep "sekularisasi"-nya atau "desakralisasi".

Nurcholish Madjid mendapatkan pendidikan dasar (SR) di Mojoanyar dan Bareng, Selain belajar di Sekolah Rakyat, dia juga belajar di Madrasah Ibtidaiyah al-Wathaniyah yang dikelola oleh orang tuanya sendiri di Mojoanyar, Jombang. Pada masa pendidikan dasarnya inilah, Nurcholish Madjid sudah menampakkan kecerdasannya dengan berkali-kali menerima penghargaan atas prestasinya. Hal ini menimbulkan rasa malu dan rasa kagum ayahnya karena kedudukan sang ayah saat itu sebagai pendiri dan pengajar di madrasah al-Wathaniyah. Kemudian melanjutkan pendidikan di pesantren (tingkat menengah SMP) di Pesantren Darul 'Ulum, Rejoso, Jombang. Tetapi karena ia berasal dari keluarga NU yang Masumi, maka ia tidak betah di pesantren yang afiliasi politiknya adalah NU ini, sehingga ia pun pindah ke pesantren yang modernis, yaitu KMI (Kulliyatul Mu`allimin Al-Islamiyyah), Pesantren Darus Salam di Gontor, Ponorogo. Di tempat inilah ia ditempa berbagai keahlian dasar-dasar agama Islam, khususnya bahasa Arab dan Inggris.7

Dari Pesantren Gontor yang sangat modern pada waktu itu, Nurcholish Madjid kemudian memasuki Fakultas Adab, Jurusan Sastra Arab, IAIN Syarif

\footnotetext{
${ }^{6}$ Budhy Munawar-Rachman, Ensiklopedi Nurcholish Madjid, lvi.

${ }^{7}$ Rachman, Ensiklopedi Nurcholish Madjid, liv.
}

286 | Kariman, Volume 07, Nomor 02, Desember 2019 
Hidayatullah, Jakarta, sampai tamat Sarjana Lengkap (Drs.), pada 1968. Dan kemudian mendalami ilmu politik dan filsafat Islam di Universitas Chicago, 19781984, sehingga mendapat gelar Ph.D. dalam bidang Filsafat Islam (Islamic Thought, 1984) dengan disertasi mengenai filsafat dan kalam (teologi) menurut Ibn Taimiyah. ${ }^{8}$

Sebuah pemikiran Nurcholish Madjid, yang diturunkan ke dalam wilayah pembaca melalui publikasi media cetak, penerbitan buku, selalu melahirkan reaksi spontan dan argumen-argumen yang masih membutuhkan logika-logika panjang. Dalam situasi seperti itu, sebuah gagasan Nurcholish Madjid, seringkali mengandung berbagai pernyataan-pernyataan baik yang setuju maupun yang kontra terhadap gagasan-gagasan yang digulirkan ke dalam wilayah pembaca.

beberapa pemikiran Nurcholish Madjid yang disuguhkan ke wilayah publik. Banyak berbicara tentang nilai-nilai yang dipandangnya universal, seperti demokrasi, pluralisme, egalitarisme, keadilan. Tema tersebut dielaborasi dengan berpijak pada doktrin dan sejarah umat Islam. Berikut karya-karya yang sudah diterbitkan antara lain: ${ }^{9}$

a. Islam Kemodernan dan Keindonesiaan

Buku ini merupakan kumpulan-kumpulan tulisan Nurcholish Madjid yang ditulisnya selama rentang waktu dua dasawarsa. Gagasan pokok dalam buku ini adalah "prinsip mencari dan terus mencari kebenaran, secara tiada berkeputusan dengan keyakinan bahwa Al Qur'an adalah satu-satunya sumber kebenaran yang absolut. Karya ini tersusun sebagai respon terhadap berbagai persoalan dan isu-isu yang berkembang di sekitar kemodernan, keislaman dan keindonesiaan. Karya ini juga mendapat sambutan antusias dari pembaca, hal ini ditandai dengan beberapa kali cetak ulang.

b. Islam Doktrin dan Peradaban

Buku yang terdiri dari lima bab bahasan ini merupakan refleksi penulisnya terhadap umat Islam di Indonesia khususnya dalam hal peranannya dalam pembangunan bangsa. Dalam buku ini Nurcholish Madjid juga membahas asas negara Pancasila, organisasi-organisasi politik, Golkar, pemilu, demokrasi, demokratisasi, oposisi, keadilan, dan dinamika perkembangan intelektual Islam di Indonesia. Hal yang juga cukup menarik

\footnotetext{
${ }^{8}$ Rachman , Ensiklopedi, lvi,

${ }^{9}$ http://sosbud.kompasiana.com/2012/02/20/nurcholis-majid-437058.html Diakses tanggal 18 Juli 20013 Jam: $16.42 \mathrm{Wib}$.
}

Kariman, Volume 07, Nomor 02, Desember 2019|287 


\section{Musayyidi \& Rasuki}

dari buku ini adalah keberanian dan kepolosan Nurcholish Madjid dalam berbicara oposisi di Indonesia, suatu tema yang sangat ditabukan pada masa ORBA. Nurcholish Madjid menegaskan, oposisi yang dimaksudkan adalah "oposisi yang loyal". Oposisi inilah yang dibenarkan dalam masyarakat yang memegang teguh prinsip-prinsip musyawarah. Dalam konteks ini Nurcholish Madjid menyatakan bahwa oposisi memang diperlukan, karena ia mempertajam pikiran.

c. Islam Kerakyatan dan Keindonesiaan : Pikiran-Pikiran Nurcholis Muda

Sebagai kelanjutan dari buku Nurcholis Madjid sebelumnya Islam kemodernan dan keindonesiaan gagasan dalam buku ini masih di sekitar keindonesiaan dengan penekanan khusus pada upaya menciptakan masyarakat yang berkeadilan, egaliter, demokrat dengan berlandaskan pada kemurnian tauhid.

d. Pintu-Pintu Ijtihad

Dalam buku ini bahasa yang digunakan lebih lugas, ringan dan sederhana sehingga mudah dipahami isi dan tujuannya. Namun demikian, tidaklah berarti mengurangi bobot dan gagasan serta ide dari penulisnya, akan tetapi justru merupakan keistimewaannya. Membaca buku ini akan mengantarkan pada kesejukan dalam memaknai Islam. Menurut budayawan Goenawan Moehamad, yang memberi pengantar buku ini, bahwa tulisantulisan Nurcholis Madjid tersebut tetap bertahan dalam tradisi humanis, yang juga menekankan kembali fungsi dan posisi manusia sebagai khalifah Allah di bumi.

e. Islam Agama Peradaban, Membangun Makna dan Relevansi Doktrin Islam Dalam Sejarah

Karya ini merupakan refleksi analisis yang mendalam dari seorang Nurcholish Madjid dalam memahami diskursus keislaman. Pemikiranpemikiran Nurcholish Madjid yang termuat dalam buku ini lebih diarahkan pada makna dan implikasi penghayatan iman terhadap perilaku sosial. Nurcholis Madjid dalam buku ini juga membahas tema-tema politik ajaran Islam yang telah berkembang dan mengalami deviasi dan distorsi di tangan umat Islam sendiri, sehingga menjadi mitos dan kultus. Dalam pemahaman yang lain, seringkali sulit dibedakan antara nilai-nilai Islam yang bersifat 
substansial dan fundamental dari ajaran yang sekunder dan terbuka untuk penafsiran dan bahkan perubahan.

f. Islam Agama Kemanusiaan : Membangun Tradisi dan Visi Baru Islam Indonesia

Dalam buku ini juga Nurcholish Madjid ingin mengajak kita untuk bisa memahami mana yang benar-benar agama yang karenanya bersifat mutlak, dan mana yang benar-benar sebagai budaya yang karenanya bersifat relatif dan sementara. Agama dan budaya sebagaimana sudah banyak disuarakan oleh banyak pemikir kebudayaan, pada kenyataannya tidak dapat dipisahkan, namun dapat dibedakan.

g. Khazanah Intelektual Islam, Jakarta : Bulan Bintang

Seperti dinyatakan oleh penulisnya, buku ini dimaksudkan untuk memperkenalkan kekayaan dan kejayaan intelektual Islam khususnya dalam bidang pemikiran filsafat dan teologi. Ia mmeperkenalkan sarjana-sarjana muslim klasik antara lain : Al-Kindi, al-Ghazali, Ibn ryusd, Ibn Taimiyah, Ibn Khaladun, al-Afghani dan Muhammad Abduh. Karya ini menurut Nurcholish Madjid sekadar merupakan penghantar kepada kajian dan pemikiran yang lebih luas dan mendalam tentang khazanah-khazanah intelektual Islam. Meskipun karya sebuah penghantar, tetapi ia merupakan sumbangan berharga khususnya terhadap literatur-literatur pemikiran Islam yang berbahasa Indonesia.

h. Masyarakat Religius

Buku ini yang berisi lima bab membahas konsep Islam dan kemasyarakatan, komitmen pribadi dan sosial, konsep kekeluargaan muslim, prinsip medis dan kesehatan keluarga Muslim dan konsep tentang eskatologis kekuatan supra alami. Pada akhirnya masyarakat diajak untuk menjadi sebuah masyarakat yang relegius.

i. Kaki Langit Peradaban Islam

Buku ini adalah hasil suntingan dari sebagian makalah tersebar yang pernah ditulis dan disampaikan Nurcholish Madjid di berbagai kesempatan seminar dan simposium dalam rentang waktu sekitar sepuluh tahun (19861996). Kendati setiap makalah pada mulanya ditulis untuk forum, tujuan, dan 
Musayyidi \& Rasuki

waktu yang berbeda-beda, namun kiranya tidak akan terlalu sulit menangkap benang, erah yang mempersatukan keseluruhan tema dan gagasan dasarnya. Yakni semangat dan pesan-pesan peradaban sesuatu yang memang sangat tipikal dalam pikiran-pikiran Nurcholish Madjid.

j. Bilik-Bilik Pesantren Sebuah Potret Perjalanan

Buku ini juga merupakan kumpulan makalah-makalah Nurcholis Madjid, memuat deskripsi dunia pesantren dengan segala dinamika perkembangannya, berhadapan dengan wacana modernisasi. Meskipun telah berlalu kurang lebih 20 tahun masa ditulisnya makalah. Kehadiran buku ini tetap menunjukkan signifikansinya dalam rangka mencari dan menemukan format baru dunia pesantren berhadapan dengan realitas eksternalnya yang mengitarinya.

k. Dialog Keterbukaan, Artikulasi Nilai Islam dalam Wacana Sosial Politik Kontemporer.

Berbeda dengan buku-buku Nurcholis Madjid sebelumnya, buku ini merupakan kumpulan wawancara yang berserakan di berbagai media massa dari sekitar tahun 1970-an sampai 1996-an, dengan tema yang sangat beragama dan bersifat spontan. Meliputi berbagai persoalan aktual, politik, budaya, pendidikan, demokratisasi, oposisi dan sampai pada persoalan 27 Juli. Buku ini sangat penting untuk dapat menangkap corak pemikiran religio-sosio politik Nurcholish Madjid dan merupakan buku pendukung untuk memahami karya-karya Nurcholish Madjid lainnya. Kata pengantar dalam buku ini secara panjang lebar dihantarkan oleh pengamat politik Fachry Ali.

\section{Memahami Pendidikan Pluralisme Dalam perspektif Nurcholish Madjid}

Paradigma dari teologi inklusif Nurcholish adalah komitmennya yang kuat terhadap persoalan pluralisme. Kesadaran akan hal ini lahir dalam diri Nurcholish sebagai akibat dari keprihatinannya yang sangat mendalam menyaksikan konflik agama. Menyaksikan kenyataan kehidupan sejarah umat manusia modern yang penuh ironi tersebut itulah yang telah menghujat kesadaran Nurcholish untuk mempertanyakan secara mendalam: beginikah hakikat agama, hakikat Islam?

Bertolak dari keyakinan itu, maka gugatan mendasar yang dilancarkan oleh Nurcholish adalah pandangan keagamaan yang bersifat eksklusivistik, 
pandangan keagamaan yang cenderung merongrong persaudaraan kemanusiaan uiversal, hanya karena perbedaan kitab suci dan Nabi yang membawanya.

Pertama-tama, Nurcholish menegaskan bahwa masalah pluralisme (dalam arti apa pun bentuknya) bukanlah sesuatu yang unik dan diherankan, terlebih lagi di jaman modern, sebab secara sosiologis pun realitas kemajemukan selalu ada. "Tidak ada suatu masyarakat tanpa pluralitas", ${ }^{10}$ Tetapi, Nurcholish meyakinkan bahwa terdapatnya perbedaan itu tidak berarti kesatuan atau ketunggalan tidak bisa diwujudkan, meskipun keadaan menjadi satu (being united) tersebut sifatnya relatif dan tetantif.

Nurcholis Madjid memaknai : "pluralisme" sebagai suatu sistem nilai yang memandang secara positif-optimis terhadap kemajemukan itu sendiri, dengan menerimanya sebagai sebuah kenyataan dan berbuat sebaik mungkin berdasarkan kenyataan itu. ${ }^{11}$ Alwi Shihab memberikan bebeapa pengertian pluralisme tidak semata-mata menunjuk pada kenyataan adanya kemajemukan, tetapi juga keterlibatan aktif terhadap kenyataan kemajemukan tersebut, dalam usaha memahami perbedaan dan persamaan guna tercapainya kerukunan dalam kebhinekaan. $^{12}$

Adapun menurut Gus Dur pluralisme maupun multikulturalisme bukanlah ide yang menyatakan semua agama sama dengan ajaran atau aqidah yang dianut. ${ }^{13}$ Namun kita semua menyadari dan mengakui, bahwa setiap agama mempunyai ajaran yang berbeda-beda. Karena perbedaan pendapat itu penting, tetapi pertentangan dan keterpecah-belahan adalah sebuah malapetaka. Dengan demikian, Nampak bahwa perbedaan yang menjadi inti sikap dan pandangan perorangan harus dibedakan dari peretentangan dan keterpecah-belahan dari sebuah totalitas masyarakat. ${ }^{14}$

Bagi Nurcholish, pluralisme tidak saja mengisyaratkan adanya sikap bersedia mengakui hak kelompok lain untuk ada, tetapi juga mengandung makna kesediaan berlaku adil kepada kelompok lain atas dasar perdamaian dan saling menghormati. ${ }^{15}$ Pluralisme di samping dapat mengantarkan seseorang pada terbentuknya sikap relativisme internal, kritis reflektif dan terbuka, juga dapat membentuk sikap arif, dialogis, tidak hitam putih, dan sekaligus mampu

\footnotetext{
${ }^{10}$ Ibid., 173.

${ }^{11}$ Ibid., 1xxviii.

${ }^{12}$ Alwi Shihab, Islam Inklusif, (Bandung: Mizan, 1999), 41

${ }^{13}$ Abdurrahman Wahid, Islamku Islam Anda Islam Kita, (Jakarta : The Wahid Institute, 2006) 135.

${ }^{14}$ Ibid., 28.

${ }^{15}$ Rachman, Ensiklopedi Nurcholish Madjid 2698.
}

Kariman, Volume 07, Nomor 02, Desember 2019|291 


\section{Musayyidi \& Rasuki}

membedakan mana ajaran yang murni dan mana pula yang merupakan tafsir terhadap ajaran sehingga terhindar dari sikap fanatisisme sempit dan pada akhirnya dapat bersikap inklusif. ${ }^{16}$

Bagi Nurcholish, paham kemajemukan masyarakat yang dimiliki ajaran Islam merupakan salah satu nilai keislaman yang sangat tinggi bagi kemodernan dan merupakan salah satu ajaran pokok Islam yang sangat relevan dengan zaman sekarang. ${ }^{17}$ Pluralisme dalam Islam yang kemudian melahirkan adanya konsep ahl al-Kitab, yang dari konsep ahl al-Kitab itulah melahirkan konsep zimmah yakni perlindungan, dalam hal ini perlindungan kepada golongan non-Muslim penganut kitab suci. Karena itu dalam pandangan Nurcholish ahl al-Kitab juga disebut golongan ahl al-zimmah atau kaum zimmi, yang berarti "mereka yang harus dilindungi". Dalam hal ini lanjut Nurcholish Nabi mengingatkan dalam sebuah sabdanya "barang siapa yang menyakiti seorang zimmi maka ia tidak termasuk golonganku" (man 'aza zimmiyan fa laysa minni). ${ }^{18}$

Atas dasar proposisi dan konstruksi pemikiran yang demikian, adalah wajar jika dalam pandangan Nurcholish, nilai-nilai pluralisme-multikultural menjadi basis ontologi, basis epistemologi dan basis aksiologis dalam pengembangan konstruksi pendidikan agama (Islam) dalam mewujudkan tujuannya, sehingga menjadi wajar pula jika tema tersebut menjadi ide pokok atau metanarasi dalam konstruksi hamper keseluruhan gagasannya tentang upaya peningkatan kualitas pendidikan agama Islam dalam maknanya yang luas dan mencakup.

Selanjutnya Nurcholish Madjid, mengungkapkan tanggapannya tentang pluralisme dalam buku yang dikutip oleh Budhy Munawar-Rachman mengatakan bahwa:

Pluralisme tidak dapat dipahami hanya dengan mengatakan bahwa masyarakat kita majemuk, beraneka ragam, terdiri dari berbagai suku dan agama, yang justru hanya menggambarkan kesan fragmentasi, bukan pluralisme. Pluralisme juga tidak boleh dipahami sekadar sebagai "kebaikan negative" (negative good), hanya ditilik dari kegunaannya untuk menyingkirkan fanatisme (to keep fanaticism at

\footnotetext{
${ }^{16}$ Seseorang yang telah memahami dan menyadari akan pluralisme, sesungguhnya telah mengamalkan filosofi alQur'an wa fawqa kulli dhi'ilmin 'alim (dan di atas setiap orang yang berilmu, ada Dia Yang Maha Berilmu) (QS.Yusuf/12: 76). Pandangan dasar inilah menurut Nurcholish yang mesti diinsyafi dalam mencoba memahami sesuatu, khususnya agama, sehingga bertitik tolak dari perspektif tersebut, relativisme dan kenisbian suatu pemahaman dapat dikonstruksi dan dikembangkan lebih lanjut sehingga menstimulasi dinamika pengembangan intelektualitas dan selanjutnya dapat mengantarkan pada kemajuan kehidupan.

${ }^{17}$ Jalaluddin Rakhmat, et al, Tharikat Nurcholishy, 41-42

${ }^{18}$ Madjid, Islam Doktrin, xci
} 
bay). Pluralisme harus dipahami sebagai "pertalian sejati kebinekaan dalam ikatan-ikatan keadaban" (genuine engagement of diversities within the bonds of civility). Bahkan pluralisme adalah juga suatu keharusan bagi keselamatan umat manusia, antara lain melalui mekanisme pengawasan dan pengimbangan yang dihasilkannya. Dalam kitab suci justru disebutkan bahwa Allah menciptakan mekanisme pengawasan dan pengimbangan antara sesama manusia guna memelihara keutuhan bumi, dan merupakan salah satu wujud kemurahan Tuhan yang melimpah kepada umat manusia. ${ }^{19}$

Kemudian, secara teologis hukum pluralitas adalah kepastian (taqdir menurut maknanya dalam Al-Qur'an) dari Tuhan. Oleh karena itu, menurutnya, yang diharapkan dari setiap masyarakat ialah menerima kemajemukan itu sebagaimana adanya kemudian menumbuhkan sikap bersama yang sehat dalam rangka kemajemukan agama itu sendiri. Sikap yang sehat itu adalah dengan menggunakan segi-segi kelebihan masing-masing umat untuk secara maksimal mendorong dalam usaha mewududkan berbagai kebaikan dalam masyarakat. Adapun masalah perbedaan itu diserahkan sepenuhnya kepada Tuhan semata. ${ }^{20}$ Sebagai ketentuan Ilahi, kemajemukan termasuk kedalam kategori sunnatullah yang tak terhindarkan karena kepastiannya. ${ }^{21}$ Tentusaja, dan tidak perlu lagi ditegaskan, perbedaan yang dapat ditenggang itu ialah yang tidak membawa kepada kerusakan kehidupan bersama. ${ }^{22}$

Hubungan islam dan pluralisme memiliki dasar argumentasi yang kuat. Menurut Nurcholish Majid hal itu berangkat dari semangat humanitas dan universalitas Islam. Di sisi lain, dalam pandangan Nurcholish Madjid bahwa kehidupan manusia secara fitri bersifat kemasyarakatan yang hidup dalam suatu bentuk hubungan tertentu dengan dunia sekitarnya. Kebutuhan, keuntungan, kepuasan, karya dan kegiatan manusia tidak mungkin terpenuhi dengan baik tanpa berada di tengah sesamanya dalam suatu perangkat tradisi dan sistem tertentu. Dengan demikian, manusia memerlukan adanya sebuah sistem sosial

\footnotetext{
${ }^{19}$ Budhy Munawar-Rachman. Islam Pluralis. Jakarta. Srigunting. 2001. Hal. 39.

20 "Dan Kami telah turunkan kepadamu Al Quran dengan membawa kebenaran, membenarkan apa yang sebelumnya, Yaitu Kitab-Kitab (yang diturunkan sebelumnya) dan batu ujian terhadap Kitab-Kitab yang lain itu; Maka putuskanlah perkara mereka menurut apa yang Allah turunkan dan janganlah kamu mengikuti hawa nafsu mereka dengan meninggalkan kebenaran yang telah datang kepadamu. (Q.S. Al-Maidah:48).

${ }^{21}$ Bahwa sunnatullah tetap dan tidak akan berubah-ubah, ditegaskan dalam Al-Qur'an surat Al-Fathir, 35:43.

"Tiadalah yang mereka nanti-nantikan melainkan (berlakunya) sunnah (Allah yang telah berlaku) kepada orangorang yang terdahulu*. Maka sekali-kali kamu tidak akan mendapat penggantian bagi sunnah Allah, dan sekalikali tidak (pula) akan menemui penyimpangan bagi sunnah Allah itu. *(Yang dimaksud dengan sunnah orangorang yang terdahulu ialah turunnya siksa kepada orang-orang yang mendustakan rasul)

${ }^{22}$ Nurcholis Madjid, Islam Doktrin, 155-156.
} 


\section{Musayyidi \& Rasuki}

yang memiliki dimensi-dimensi ketuhanan. Kontualisasi ini tidak lain dari upaya menemukan titik temu antara hakikat Islam dan semnagat zaman. Hakikat Islam, kerahmatan dan kesemestaan (Rahmat Lil 'Alamin), Pencapaian cita-cita kerahmatan dan kesemestaan (dalam ungkapan lain kemaslahatan untuk semua), ${ }^{23}$ dengan demikian, Sikap pri kemanusiaan menghasilkan amal saleh, artinya amal yang bersesuaian dengan dan meningkatkan kemanusiaan. Sebaik-baiknya manusia ialah yang berguna untuk sesamanya.

Pendeknya, Nurcholis hendak mengiring bahwa umat islam Indonesia pun harus bisa mewarisi semangat pluralisme yang tinggi. Ia selalu menekankan baik pada umat islam sendiri maupun nonmuslim bahwa bersikap positif pada pluralisme adalah suatu keharusan, bukan saja karena doktrin agama memang mendukung demikian, tetapi terlebih karena tuntutan objektif dari realitas kehidupan modern.

Dari pemaparan tentang pengertian pluralisme, ada beberapa ciri tentang pemikiran yang pluralisme antara lain sebagai berikut:

1) Adanya sikap netral terhadap perbedaan ras, suku, dan agama.

2) Menjalin suatu kerjasama yang baik.

melihat urgennya mengintegrasikan kembali inklusivitas ajaran Islam yang merupakan substansi ajaran Islam agar Islam tampil dalam wajah yang sesungguhnya, yaitu pluralis, toleran, humanis, transformatif, aktual, dan egalitarian. $^{24}$

Oleh karena itu, ada beberapa alternatif model pembelajaran (pendidikan agama Islam) yang mestinya dilakukan oleh para guru mata pelajaran agama Islam agar menghasilkan out-put pendidikan yang inklusif, berwawasan pluralis, dan apresiatif terhadap perbedaan.

Dengan menyadari bahwa masyarakat kita terdiri dari banyak suku dan beberapa agama, jadi sangat pluralis. Maka, pencarian bentuk pendidikan alternatif mutlak diperlukan. Yaitu suatu bentuk pendidikan yang berusaha menjaga kebudayaan suatu masyarakat dan memindahkanya kepada generasi berikutnya, menumbuhkan akan tata nilai, memupuk persahabatan antara siswa

\footnotetext{
${ }^{23}$ Jalaluddin Rakhmat, et al, Tharikat Nurcholishy, "Jejak Pemikiran Dan Pembaharuan Sampai Guru Bangsa", (Yogyakarta: Puataka pelajar, 2001) 41

${ }^{24}$ Islam menghendaki suatu sistem yang menguntungkan semua pihak termasuk non-Islam. Pandangan ini menurut Nurcholis Madjid sudah mendapatkan dukungan dalam sejarah Islam sendiri atau kita mengambil legitimasi al-Qur'an bahwa ajaran Islam pada hakikatnya - sebagaimana merupakan Hakikat Islam, kerahmatan dan kesemestaan (Rahmat Lil 'Alamin), Pencapaian cita-cita kerahmatan dan kesemestaan (dalam ungkapan lain kemaslahatan untuk semua) lihat Jalaluddin Rakhmat, et al, Tharikat Nurcholishy, "Jejak Pemikiran Dan Pembaharuan Sampai Guru Bangsa", (Yogyakarta: Puataka pelajar, 2001) 41
} 
yang beraneka ragam suku, ras, dan agama, mengembangkan sikap saling memahami, serta mengerjakan keterbukaan dan dialog. Bentuk pendidikan seperti inilah yang banyak ditawarkan oleh "banyak ahli" dalam rangka mengantisipasi konflik keagamaan dan menuju perdamaian abadi, yang kemudian terkenal dengan sebutan "pendidikan pluralisme".

Menyadari uraian di atas, persoalan yang dihadapi oleh pendidikan agama adalah bagaimana mampu menghadirkan konstruksi wacana keagamaan yang kontekstual dengan perubahan masyarakat. Selanjutnya, bagaimana konstruksi wacana keagamaan tersebut mampu ditransformasikan dalam masyarakat secara sistemik dalam kehidupan bermasyarakat. Menurut A. Malik Fajar inilah persoalan fundamental yang dihadapi pendidikan agama saat ini. ${ }^{25}$

Ketika pendidikan agama Islam masih diajarkan dengan semangat ketertutupan yang cenderung tidak ada nuansa toleransi, jangan banyak berharap pendidikan agama Islam dapat turut meredam gejolak sosial yang sedang melanda bangsa ini. Oleh karena klaim kebenaran tidak akan melahirkan kecuali output yang eksklusif, Dari sudut sosiologis klaim kebenaran sudah banyak melehirkan berbagai konflik sosial-politik yang membawa perang antar agama yang sampai saat ini masih menjadi problem dan kenyataan yang tidak bisa dihindari. ini berasal dari dan menuju Tuhan (Inna li l-Lah-I wainna ilayh-I raji'un. "Sesungguhnya kita bersal kita berasal dari Tuhan dan kita akan kembali kepadaNya"), maka Tuhan adalah "sangkan paran" (asal dan tujuan) hidup, bahkan seluruh makhluk (dumadi). ${ }^{26}$

ketuhanan Yang Maha Esa adalah inti semua agama yang benar. Tuhan adalah pencipta semua wujud yang lahir dan batin, untuk diangkat menjadi wakil (khalifah)-Nya dibumi. ${ }^{27}$ Setiap pengelompokan (umat) manusia telah pernah mendapatkan ajaran tentang ketuhanan Yang Maha Esa melalui para rasul Tuhan. Karena itu, terdapat titik peremuan (kalimah sawa') ${ }^{28}$ antara semua agama

\footnotetext{
${ }^{25}$ A. Malik Fajar, Reorientasi Pendidikan Islam (Jakarta: Fajar Dunia, 1999) 131-132.

${ }^{26}$ Ungkapan "sangkan paraning dumadhi/hurip"erdapat dalam perbedaan spritualisme jawa yang diketahui banyak sekali mengambil dari gagasan-gagasan sufi Islam. Diduga ungkapan itu merupakan terjemahan ayat Al-Qur'an, s. Al-Baqarah, 2:156, Inna li l-Lah-I wainna ilayh-I raji'un.

${ }_{27}$ Penciptaan manusia sebagai makhluk yang setinggi-tingginya adalah sesuai denfgan maksud dan tujuan diciptakannya manusia itu untuk menjadi khalifah (secara harfiah berarti "yang mengikuti dari belakang", jadi "wakil" atau berganti") di bumi, dengan tugas menjalankan "mandate" yang diberikan Allah kepadanya membangun dunia ini sebaik-baiknya: "

${ }^{28}$ Istilah Arab kalimah sawa' berarti kalimat, idea tau prinsip yang sama, yakni ajaran yang menjadi "commom platform" antara berbagai kelompok manusia.
}

Kariman, Volume 07, Nomor 02, Desember 2019|295 
Musayyidi \& Rasuki

manusia, dan orang-orang muslim diperintahkan untuk mengembangkan titik pertemuan itu sebagai landasan hidup bersama. ${ }^{29}$

\section{Gagasan Pembaharuan Pendidikan Islam}

Gagasan pembaharuan Pendidikan Islam di Indonesia adalah berangkat dari sistem pendidikan tradisional dan modern. ${ }^{30}$ Sistem pendidikan Islam tradisional tergolong memiliki muatan edukasi yang konservatif. . Menurut Nurcholish Madjid kultur ini tidak member kebebasan berfikir yang berakibat pada kurangnya kemampuan seseorang dalam mengimbangi dan menguasai kehidupan global bahkan memberi respon. Pendidikan Islam menurut Nurcholis Madjid harus dapat memberikan arah pengembangan dua dimensi bagi peserta didik, yakni dimensi ketuhanan dan dimensi kemanusiaan.

Nurcholish Madjid mengalami perubahan paradigma berpikir setelah kunjungan pertama ke negeri paman Sam (Amerika). Simpul pemikiran Nurcholish Madjid adalah monoteisme radikal dan kemodern. Sehingga memunculkan gagasan-gagasan tentang sekularisasi serta inklusivisme dan universalisme Islam. $^{31}$ Dari pemaparan tersebut, ada beberapa ciri tentang Gagasan pembaharuan Nurcholis Madjid antara lain sebagai berikut:

a. Sekularisasi versi Nurcholish adalah menduniawikan nilai-nilai yang semestinya bersifat duniawi dan melepaskan umat Islam dari kecenderungan mengakhiratkannya.

b. Gagasan inklusivisme dan universalisme Islam dalam pendapat Nurcholish bahwa Islam tidak identik dengan ideologi.

Konsep pembaharuan Pendidikan Islam yang digagas Nurcholish Madjid secara garis besar Variannya antara lain gagasan tentang sekularisasi ${ }^{32}$ serta inklusivisme dan universalisme Islam kebebasan intelektual dan sikap terbuka terhadap ide yang baru. Sekularisasi dalam pengertian Madjid adalah proses pemahaman rasional untuk mendominasikan nilai-nilai yang bersifat duniawi. ${ }^{33}$

\section{Pendidikan pesantren sebagai Basis Mewujukan Nilai-nilai Pluralisme}

Pesantren adalah pusaka bangsa yang merupakan salah satu institusi pendidikan dengan struktur dan kultur sosial yang unik, pesantren merupakan

\footnotetext{
${ }^{29}$ Nurcholis Madjid, Islam Doktrin, 3.

${ }^{30}$ Madjid, Islam Doktrin, 1xiii.

${ }^{31}$ Rachman, Ensiklopedi, lvi, Madjid, Islam Agama, 224,

${ }^{32}$ Nurcholis Madjid, Islam Kemodernan dan Keindonesiaan, (Bandung : Mizan, 2008) 230.

${ }^{33}$ Ibid., 230.
} 
lembaga pendidikan sangat efektif dan berpengaruh besar bagi proses penyebaran dan kelanjutan dan pengembangan lembaga serupa di dunia Islam. Dalam lingkungan pesantren memiliki kemampuan untuk menciptakan pola hidup persaudaraan yang ramah, disertai jiwa kebersamaan yang ramah, keterbukaan kemandirian, dan kebebasan yang bertanggung jawab. Tidak jarang kita temui Pilihan untuk menyelenggarakan sistem pendidikan dengan menerapkan model pesantren sekarang sudah umum dilakukan orang. bertanggung jawab. Faktanya Kelebihan sistem ini dibanding dengan sistem sekolah biasa dimana suasana pendidikan selama $24 \mathrm{jam}$, dan para pendidik atau pengasuh dapat mengawasi, membimbing, dan memberi teladankepada mereka secara total. Ini akan memudahkan intensifikasi usaha pencapaian tujuan-tujuan pendidikan, ${ }^{34}$

Dapat difahami bahwa Pesantren merupakan Institusi pendidikan yang mampu berperan dalam menyongsong masyarakat madani adalah institusi pendidikan yang mempunyai unsur perpaduan antara nilai keislaman, keindonesiaan, dan keilmuan. Perpaduan tiga dimensi itu dijadikan landasan filosofis dalam memodernisasi pendidikan Islam seperti pesantren.

Untuk dapat mewujudkan masyarakat madani melalui pesantren, maka yang dapat dilakukan salah satunya dengan reaktualisasi nilai-nilai pluralisme dalam pendidikan pesantren. Selama ini yang ghalib terjadi adalah adanya berbagai konsep dan paradigma yang masih intoleran, kaku, dan eksklusif dalam memandang "the others" atau orang di luar akidah, keimanan, dan keyakinannya. Masih banyaknya truth claim individu, kelompok, organisasi, atau instansi tertentu, tanpa bisa meyakini dan menghormati bahwa suatu kebenaran juga mungkin ada pada orang lain dan kepercayaannya. sehingga realitas sistem pendidikan pesantren sangat berpotensi dan mempunyai untuk menanamkan nilai-nilai pluralisme pendidikan islam untuk mewujudkan masyarakat madani.

\section{Kesimpulan}

Menurut Nurcholish Madjid konsep Pendidikan Pluralisme merupakan suatu pendidikan untuk menerima kemajemukan termasuk kedalam kategori sunnatullah yang tak terhindarkan karena kepastiannya. Yaitu suatu bentuk pendidikan nilai yang memupuk persahabatan antara siswa yang beraneka ragam suku, ras, dan agama, dalam usaha memahami perbedaan dan persamaan guna tercapainya kerukunan dalam kebhinekaan. menghindari perpecahan,

\footnotetext{
${ }^{34}$ Rachman, Ensiklopedi Nurcholish Madjid" 2668- 2669
}

Kariman, Volume 07, Nomor 02, Desember 2019|297 
Musayyidi \& Rasuki

mengembangkan kerjasama dengan menanamkan rasa saling memahami, pengertian, saling memiliki dan bersikap inklusif, tidak membatasi pergaulan dengan siapapun, namun tetap meyakini kebenaran agama sendiri dengan tidak mempersamakan keyakinan secara total.

Dalam perspektif pendidikan Islam, gagasan dan pemikiran Nurcholish Madjid tentang Pluralisme Pendidikan Islam memiliki keserasian yaitu berorientasi pada terbentuknya keshalehan indiviu, kepribadian, serta akhlak yang luhur, "kepatuhan dan ketaatan" yakni sikap pasrah kepada tuhan (al-islam) dengan berdasarkan al- Qur'an dan al-Hadits, serta berorientasi pada terbentuknya Ummatan Wahidah, ummatan wasathan, dan upaya terwujudnya baldatun thayyibah sebagai Hakikat Islam, kerahmatan dan kesemestaan (Rahmat Lil 'Alamin).

\section{DAFTAR PUSTAKA}

Fajar, A Malik, 1999. Reorientasi Pendidikan Islam. Jakarta: Fajar Dunia.

Madjid, Nurcholis, 2008. Islam Doktrin Peradaban. Jakarta: Paramadina.

Madjid, Nurcholish, 2008. Islam kemodernan dan keindonesiaan. Bandung: Mizan.

majid, Abdul andiyani, dian, 2005. pendidikan agama Islam bebrbasis kompentensi. bandung: remaja rosdakarya.

Nata, Abudin 2005. Tokoh-Tokoh Pembaharuan Pendidikan Islam Di Indonesia. Jakarta: Raja Grafindo persada.

Nata, Abudin, 2009.Metodologi Studi Islam. Jakarta: PT. Raja Grafindo Persada, Rachman, Budhy Munawar, 2004. Islam Pluralis, Wacana Kesetaran Kaum Beriman. Jakarta: PT. Raja Grafindo Persada

Rakhmat, Jalaluddin, et al, 2001. Tharikat Nurcholishy, "Jejak Pemikiran Dan Pembaharuan Sampai Guru Bangsa". Yogyakarta: Puataka pelajar.

Shihab,Alwi, 1997. Islam Inklusif: Menuju Sikap Terbuka dalam Beragama. Bandung: Mizan.

Tilaar, H.A.R, 2003. Kekuasaan dan pendidikan "Suatu Tinjauan dari Perspektif Studi Kultural". Magelang: Indonesiatera.

Wahid,Abdurrahman, 2006. Islamku Islam Anda Islam Kita. Jakarta: The Wahid Institute 